\title{
Characterizing Campus Open Spaces of University of the Philippines Diliman Based on Utilization and Perception of Outdoor Thermal Comfort
}

\author{
Glenn T. Orbon ${ }^{1}$, Genelyn Ma.F. Sarte ${ }^{2}$, Claudia Isabelle V. Montero ${ }^{1}$, Regina Starr \\ B. Abelardo ${ }^{3}$ \\ ${ }^{I}$ College of Architecture, University of the Philippines Diliman, Quezon City, 1101 Philippines \\ ${ }^{2}$ School of Statistics, University of the Philippines Diliman, Quezon City, 1101 Philippines \\ ${ }^{3}$ College of Arts and Letters, University of the Philippines Diliman, Quezon City, 1101 \\ Philippines
}

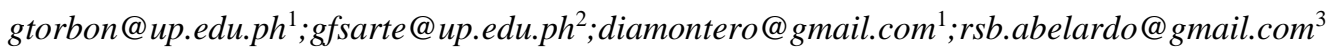

Received: 2 February 2018 Final Version Received: 28 August 2019

\begin{abstract}
Outdoor open spaces are essential to the physical development of the University of the Philippines (UP) towards its pursuit of academic excellence, especially since the balance between "green" open spaces and built environment is a vital part in designing an urban campus. Specifically, thermal comfort and climate change are important factors to consider in providing a comfortable learning environment. This study aims to determine the perception of outdoor thermal comfort and actual uses by UP Diliman students of selected outdoor open spaces vis-àvis the intended functions. Upon analysis of the behavior and preferences of UP students regarding the use of outdoor open spaces, several factors related to outdoor thermal comfort, accessibility, convenience, and landscape design have been derived, such as protection from direct sunlight, natural ventilation, lighting, benches for seating, and convenience through accessibility - all of which had been considered by the students in selecting and utilizing the selected outdoor open spaces. Moreover, these outdoor spaces exhibit flexibility in terms of their uses and functions for the students and the public.
\end{abstract}

Keywords: Outdoor Thermal Comfort, Tropical Climate, Open Spaces, Campus Grounds, Campus Design and Planning

\section{INTRODUCTION}

The climate of the Philippines is hot and humid largely due to its geographical location and physical characteristics - situated in the tropics, surrounded by bodies of water as an archipelagic country, presence of tropical rainforests, and high exposure to weather disturbances such as tropical cyclones and monsoon rains. The combination of humidity and the usual high temperature as a tropical country contributes to the higher heat index in most areas, especially during the summer months of April and May.

Many researches have been conducted on indoor thermal comfort. However, studies on outdoor thermal comfort have just been started in the recent years, but not so much for areas with hot and humid climates such as the Philippines. The lack of studies on outdoor thermal comfort is probably due to the wide range of factors that affect outdoor spaces and environments (Makaremi et al., 2012).

Considered as the national university, the main campus of the University of the Philippines (UP) in Diliman, Quezon City is a 493-hectare campus composed of different land used for various functions. These areas are categorized in the 2012 Land Use Plan of UP Diliman: campus core, academic and academic support units, science and technology park, resource generation zone, residential or mixed use, community services, other parks and major open spaces, and protected forest area or arboretum. Each land use acts as support for other areas within the campus - in service of the university's main function of catering to the needs and rights of the Filipino people for quality education to the highest level possible. The delivery, completeness, and level of exclusivity of the support facilities and services within the campus 
are critical for the faculty, staff, and students to perform well towards achieving academic excellence (Araneta, 2009).

Outdoor open spaces, thus, are essential to the function of the university through provision of opportunities for social and recreational activities. The UP Diliman campus, highly regarded by Landscape Architect Paulo Alcazaren (2013) as an oasis of green open space in the Metropolitan Manila area, has greatly contributed in addressing the detrimental effects of the Urban Heat Island (UHI) Effect in the metro such as warmer temperature and higher heat index. The retention of open spaces, lush vegetation, and use of sustainable materials for structures and landscapes are just some of the strategies being utilized by the university to mitigate the negative impact of UHI to the habitability of the campus (Dul-loog and Galingan, 2005)

Figure 1- Approved 2012 UP Diliman Campus Land Use Plan showing the areas of various functions within the university's main campus premises. (Source: UP Office of Design and Planning Initiatives)
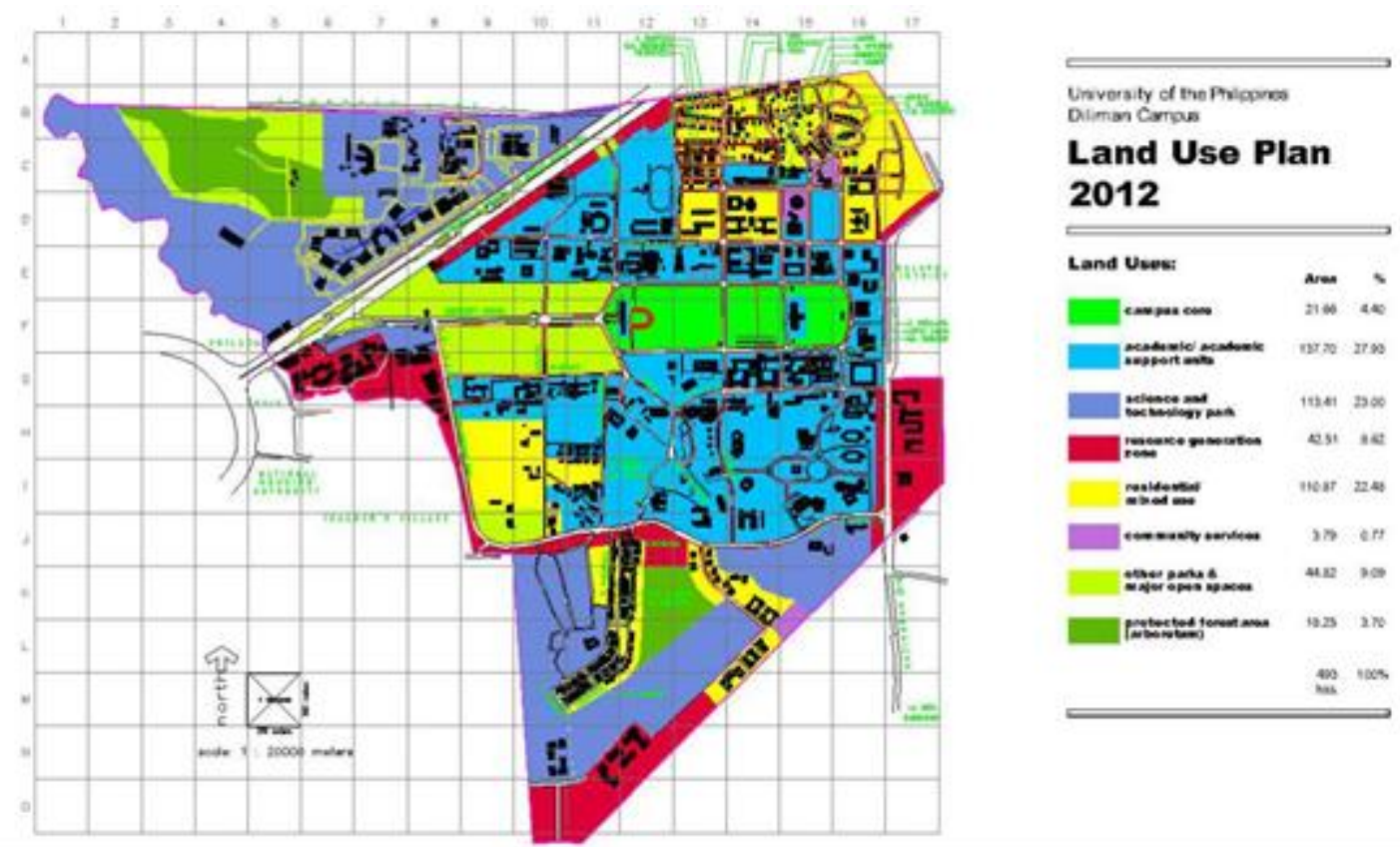

\subsection{Urban Design vis-à-vis Outdoor Thermal Comfort}

The balance between "green" open spaces and built environment such as buildings and structures is crucial in the development and planning of a campus so as to create a learning environment that is conducive to academic pursuits (Araneta, 2009). With the implementation of the academic calendar shift for all UP campuses, which changes the class period and covers regular classes during summer months, the issue on thermal comfort, both indoor and outdoor, as well as the effects of climate change have become bigger concerns in providing a comfortable learning environment.

Within the campus, outdoor open spaces - with varying urban form and fabric depending on the visible physical elements - are used as social and recreational areas not only by the UP community but also by people from outside the university. Providing comfortable outdoor open spaces within the premises of the university is then vital in campus planning and design. A "thermally comfortable outdoor environment" may affect the indoor atmosphere and may be beneficial in lowering the use of energy for space conditioning within buildings (Johansson and Emmanuel, 2006).

\subsection{Perceived Comfort and Actual Use of Outdoor Open Spaces in the University Campus}

Using selected outdoor campus grounds of UP Diliman for the case study and the UP students as user-respondents for the survey, the goal of 
this paper is to determine the perceived comfort and actual use of selected outdoor open spaces in UP Diliman vis-à-vis the intended functions of these spaces. This study aims to determine the elements and/or features that must be considered in the future design and planning for physical development of such spaces in various UP campuses based on the preferences and actual uses of outdoor open spaces by the UP students as the major users.

This study is part of a larger research entitled "Tropical Campus Grounds: Providing Thermally Comfortable Outdoor Open Spaces for the University of the Philippines Campuses," which was supported by the Office of the ViceChancellor for Research and Development (OVCRD) of UP Diliman through the Sources of Solutions (SOS) Grant [Project No. 131306 SOS]. For this study, six outdoor open spaces within the UP Diliman campus were selected based on the volume of students staying and proximity of the spaces from each other due to the limitation on tools for measurement of environmental parameters, which is part of the second phase of the research. These six outdoor open spaces were divided into three pairs based on the similarity of urban form and fabric used for comparison in determining the effects of the physical development factors to outdoor thermal comfort.
The selected study sites include the following (based on type of open space):

- Building Entrances (BE): BE1 - Palma Hall or Arts and Sciences (AS) Steps BE2 - Gonzalez Hall or UP Diliman Main Library Entrance Steps

- Large Open Fields (OF): OF1 - General Antonio Luna Parade Grounds or Sunken Garden OF2 - UP Diliman Athletic Track Oval

- Student Hangout Areas (HA): HA1 - Vinzons Hill Tambayan Complex (VHTC)

HA2 - Rizal Hall or Faculty Center (FC) hangout areas

Several General Education (GE) classes are held in Palma Hall or Arts and Sciences (AS) Building, hence, a large number of students are seen at AS Steps on school days. The University Main Library is regularly visited by students for academic and social purposes. The steps of both AS Building and Main Library serve as the main entrance to the two buildings and were converted into outdoor open spaces for various functions. While AS Building faces north, the Main Library is facing the west. Thus, both spaces are exposed to direct sunlight and natural ventilation but in a different manner at a given time.

Figure 2 - The Arts and Sciences (AS) Building Steps serves as the main entrance of Palma Hall.

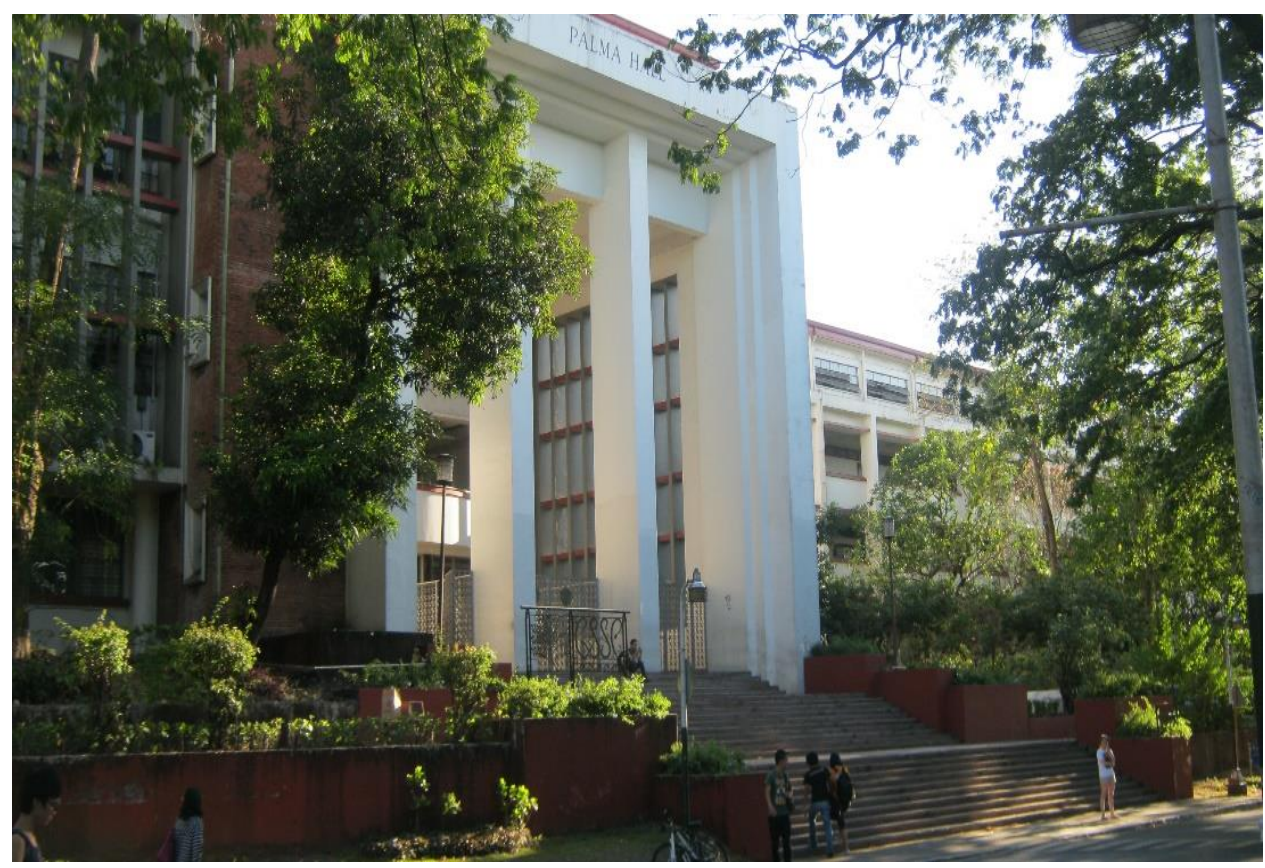


Figure 3 - Plan showing the Arts and Sciences (AS) Building Steps and the extent of study area.

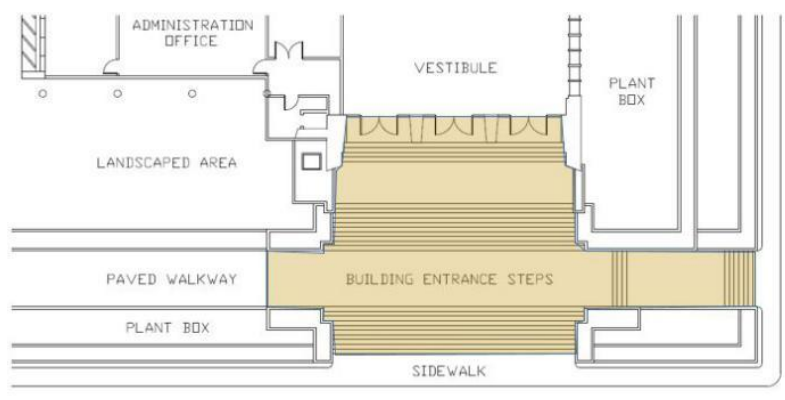

MAIN RDAD

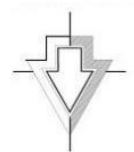

Figure 4- The road at the front of Gonzalez Hall or UP Diliman Main Library is closed to vehicular traffic except for emergencies.

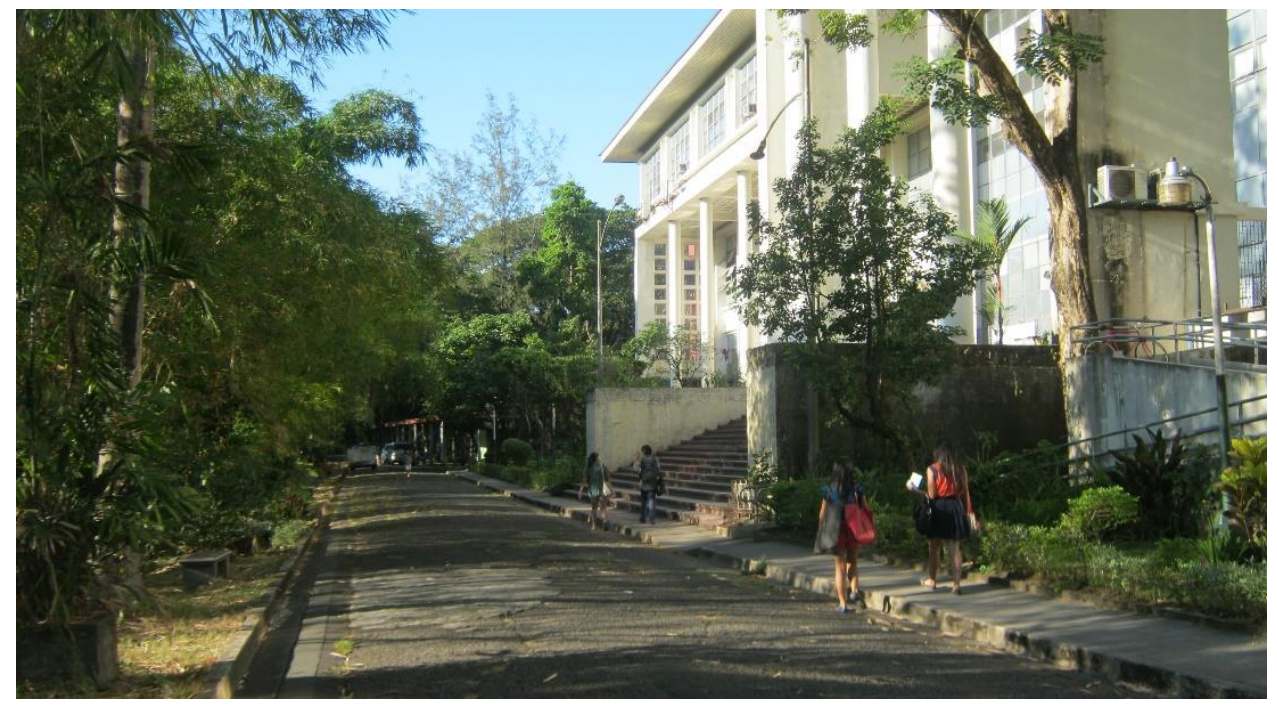

Figure 5- Plan showing the front of Gonzalez Hall or UP Diliman Main Library and the extent of study area.

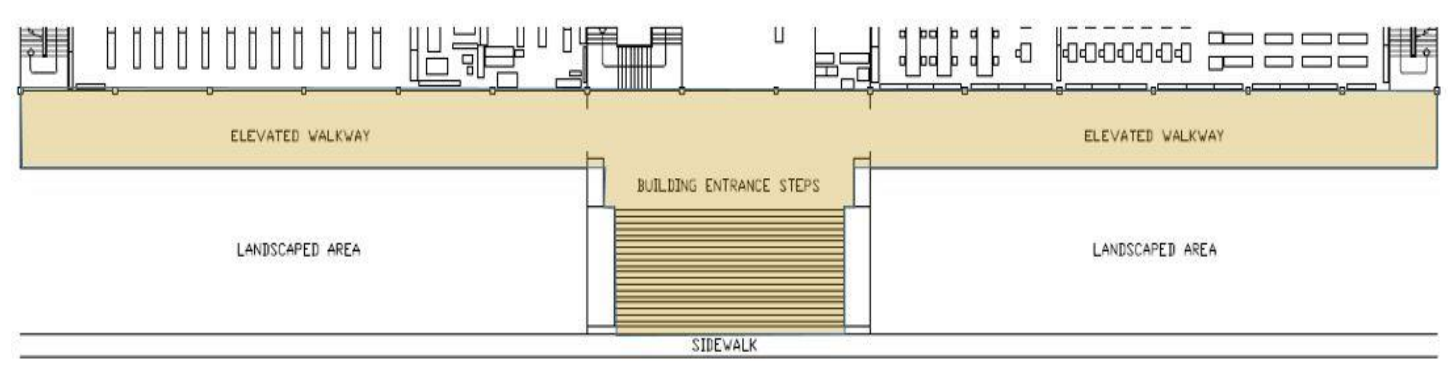

SERVICE RDAD

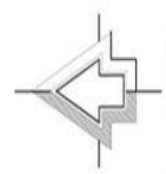


At the center of the Sunken Garden and Athletic Track Oval are large open fields where university athletes and varsity players usually practice. The former is covered with grass, while the latter, is covered mostly with dry land or dirt for sports training purposes. The higher areas at the sides are used as hangout areas by the students and the public, with the Sunken Garden having concrete benches at strategic spots while the Track Oval mostly having reused tree logs converted as seating areas. As more evident in the Sunken Garden, some people also sit and lie down on the grass. Both areas are easily accessible to the public, with the former catering to more people due to its location within the Academic Core of the campus. These areas are the most public among the selected outdoor open spaces.

Figure 6 - The Sunken Garden along the Academic Oval is open to the UP community, public and outsiders.

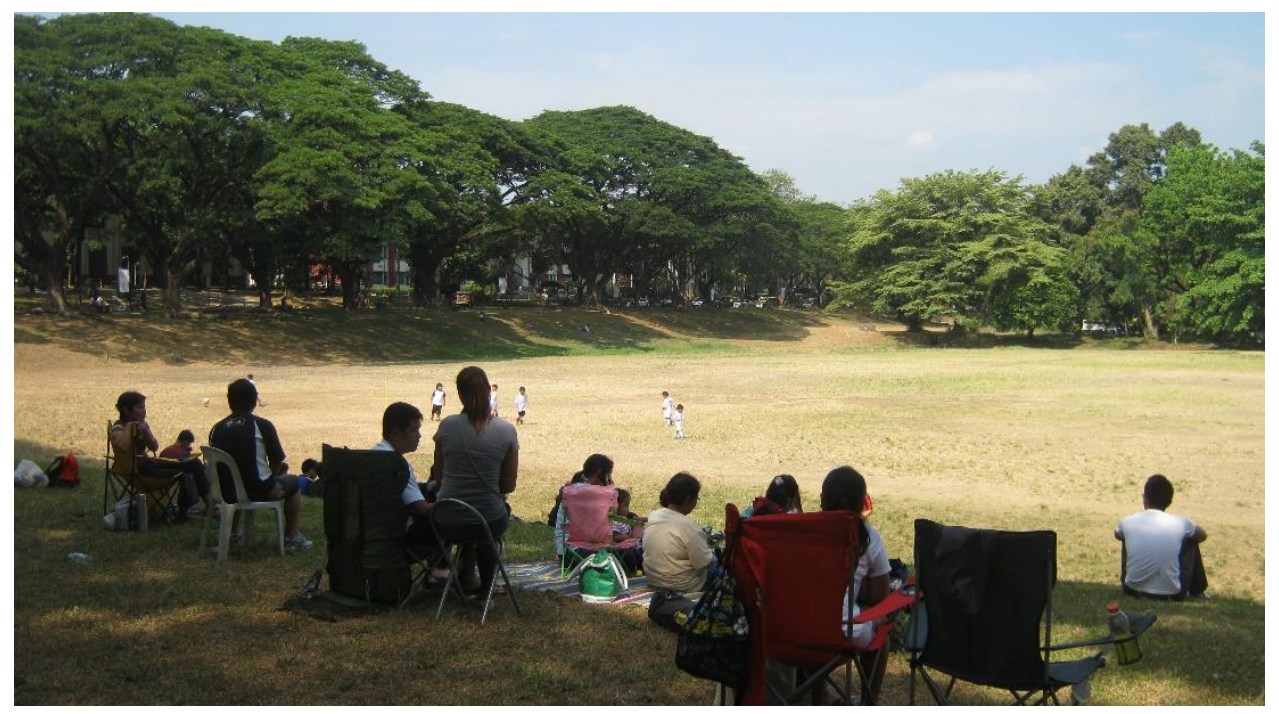

Figure 7- The UP Diliman Athletic Track Oval was used for various sports and recreational activities.

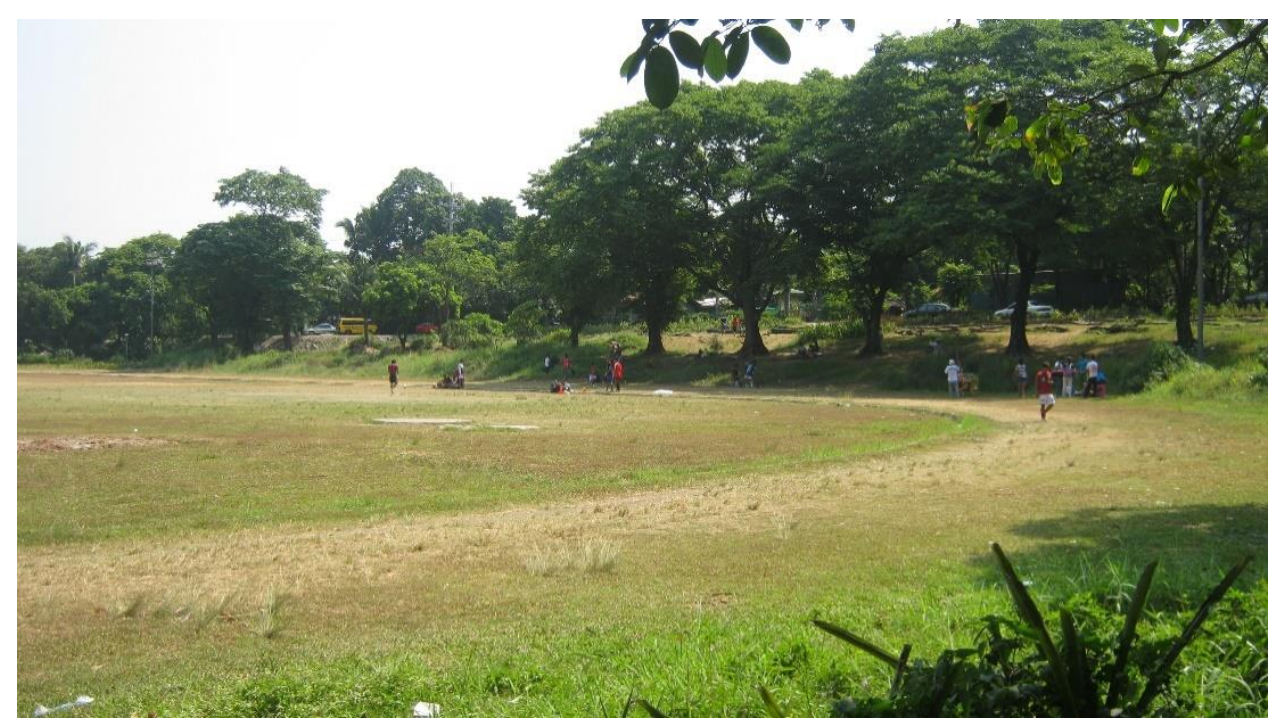

Man-made tambayans or hangout areas were built in the open spaces adjacent to Vinzons Hall and Faculty Center (FC), with the former having concrete flooring while the latter, having natural ground cover, grass. The hangout areas of Vinzons Hill Tambayan Complex (VHTC) and
FC Tambayan are usually occupied by members of student organizations in the University. While the hangout areas of VHTC are composed of materials mostly made of concrete and metal, the tambayans at the back of FC were built with bamboo and thatch. 
Figure 8 - The Vinzons Hill Tambayan Complex or VHTC houses various University-based student organizations.

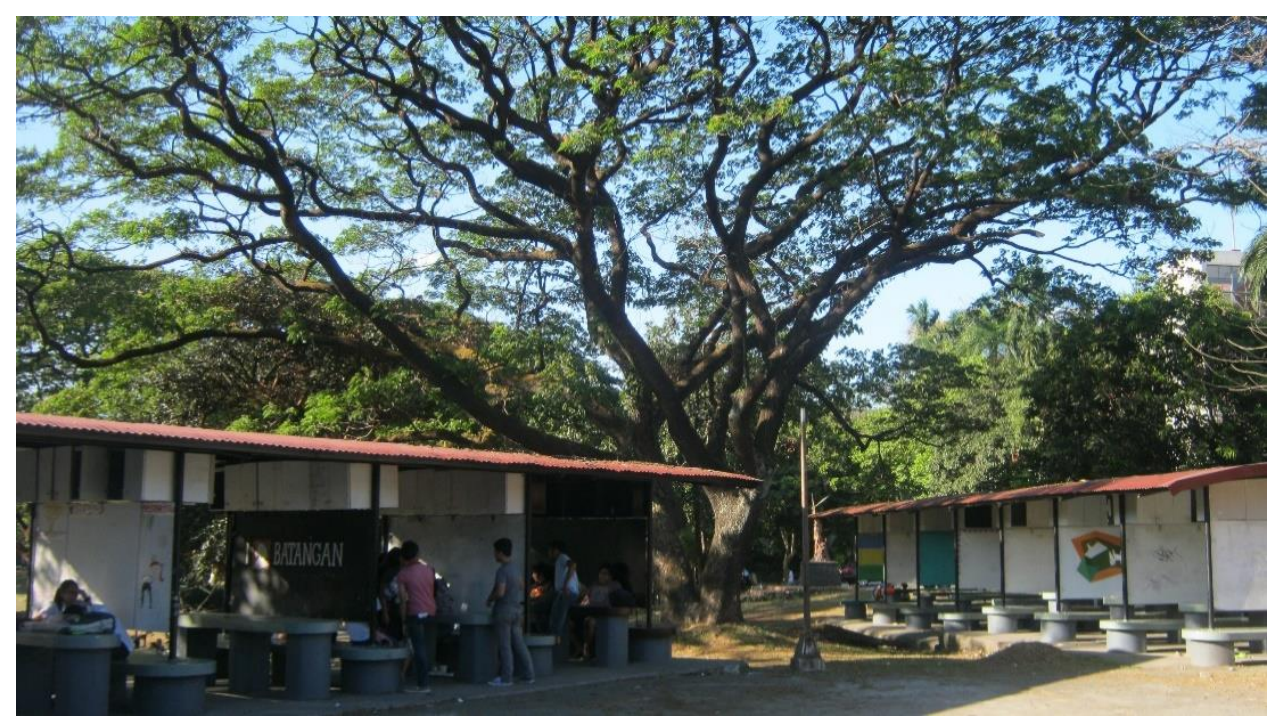

Figure 9 - The open space at the back of Faculty Center serves as space for tambayans of student organizations.

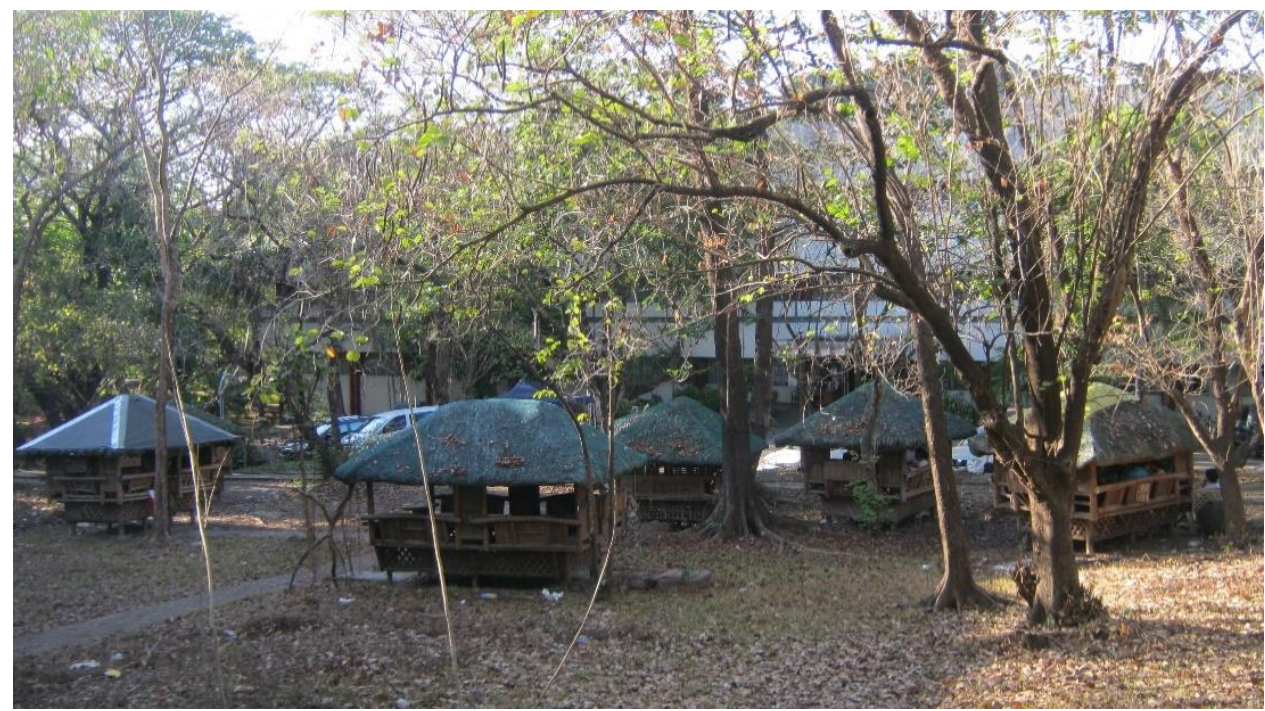

The proximity of AS Steps, Main Library Steps, and FC Tambayan from the academic buildings allows the students to stay or hang out in said spaces. Sunken Garden holds the most number of people due to its central location and accessibility for both members of the UP community and oursiders. The UP Track Oval, located near the entrance gate along Commonwealth Avenue, is also open to the public. Several outsiders are also occupying some of the spaces in the hangout areas in VHTC due to its accessibility and absence of barriers on site. 
Figures 10 and 11 - Key maps (satellite image and plan) showing a portion of UP Diliman campus and study areas: (1) AS Steps, (2) Main Library Steps, (3) Sunken Garden, (4) UP Track Oval, (5) VHTC, and (6) FC tambayans. (Sources: Office of Design and Planning Initiatives; Google Maps)
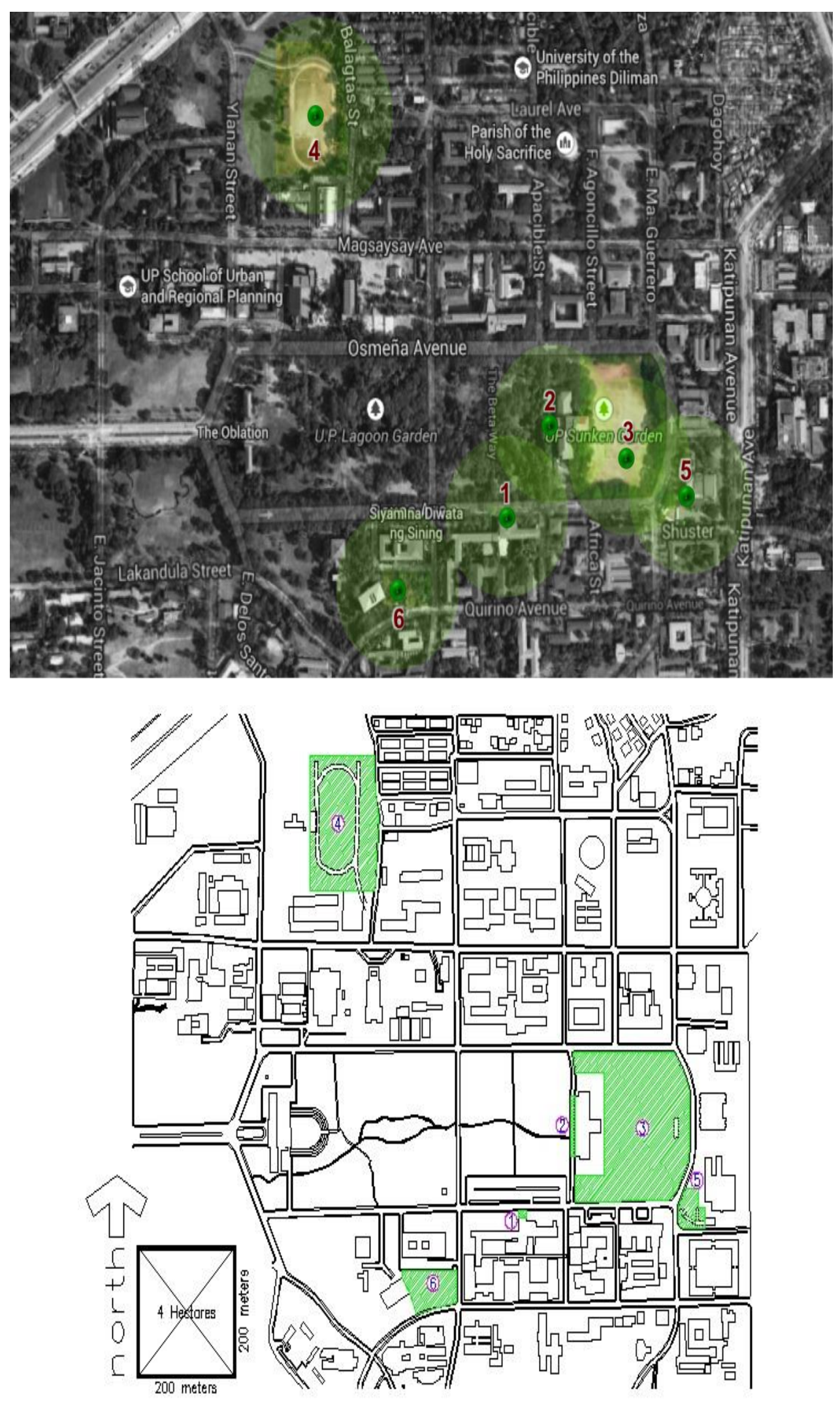
Table 1- Comparison of Study Areas - Building Entrances [BE].

\begin{tabular}{|c|c|c|}
\hline $\begin{array}{c}\text { DESCRIPTION / } \\
\text { CHARACTERISTICS }\end{array}$ & $\begin{array}{c}\text { BE1 } \\
\text { Arts and Sciences (AS) } \\
\text { Building Steps }\end{array}$ & $\begin{array}{c}\text { BE2 } \\
\text { University Main Library } \\
\text { Entrance Steps }\end{array}$ \\
\hline Approximate Floor or Land Area & $\begin{array}{l}-200 \text { square meters (excluding } \\
\text { paved walkway) }\end{array}$ & $\begin{array}{l}900 \text { square meters (including } \\
\text { elevated walkway) }\end{array}$ \\
\hline Orientation & $\begin{array}{l}\text { - facing north (building at south } \\
\text { side of steps) }\end{array}$ & $\begin{array}{l}\text { facing west (building at east } \\
\text { side of steps) }\end{array}$ \\
\hline $\begin{array}{l}\text { Features and Materials } \\
\text { - Ground Cover } \\
\text { - Vegetation } \\
\text { - Surrounding Built Structures and } \\
\text { Landscapes }\end{array}$ & \begin{tabular}{|l} 
- concrete steps w/ 3 landings \\
- no canopy or roof cover \\
- tall trees nearby (serve as \\
shade) \\
- landscaped areas (including \\
plant boxes) at the sides \\
- adjacent to main road (vehicular \\
traffic)
\end{tabular} & $\begin{array}{l}\text { concrete steps w/ } 2 \text { landings } \\
\text { (including top landing } \\
\text { connected to elevated } \\
\text { walkways both sides) } \\
\text { - with canopy or roof cover } \\
\text { (uppermost landing leading to } \\
\text { the entrance and elevated } \\
\text { walkways) } \\
\text { - tall trees nearby (serve as } \\
\text { shade) } \\
\text { landscaped areas (including } \\
\text { plant boxes) at the sides } \\
\text { - adjacent to service road (closed } \\
\text { most of the time) } \\
\text { ledges along the elevated } \\
\text { walkway that may serve as } \\
\text { informal seating areas } \\
\text { access ramp at the side } \\
\text { access stairs at the far ends of } \\
\text { the elevated walkways }\end{array}$ \\
\hline Original or Intended Function & $\begin{array}{l}\text { - serve as main access to the } \\
\text { entrance of Palma Hall or AS } \\
\text { Building }\end{array}$ & $\begin{array}{l}\text { serve as main access to the } \\
\text { entrance of Gonzalez Hall or } \\
\text { University Main Library }\end{array}$ \\
\hline
\end{tabular}

Table 2 - Comparison of Study Areas - Large Open Fields [OF].

\begin{tabular}{|c|c|c|}
\hline $\begin{array}{c}\text { DESCRIPTION / } \\
\text { CHARACTERISTICS }\end{array}$ & $\begin{array}{c}\text { OF1 } \\
\text { Sunken Garden }\end{array}$ & $\begin{array}{c}\text { OF2 } \\
\text { UP Athletic Track Oval }\end{array}$ \\
\hline Approximate Floor or Land Area & - 43,200 square meters & $\begin{array}{l}28,600 \text { square meters (only the } \\
\text { side of track oval as study area) }\end{array}$ \\
\hline Orientation & $\begin{array}{l}\text { - sloping sides at north, east, and } \\
\text { south sides (University Main } \\
\text { Library at the west side) }\end{array}$ & $\begin{array}{l}\text { - sloping side at east side (facing } \\
\text { track oval at the west side) }\end{array}$ \\
\hline $\begin{array}{l}\text { Features and Materials } \\
\text { - Ground Cover } \\
\text { - Vegetation } \\
\text { - Surrounding Built Structures and } \\
\text { Landscapes }\end{array}$ & $\begin{array}{l}\text { - central open field depressed } \\
\text { from the road level } \\
\text { - mostly covered with grass or } \\
\text { soil } \\
\text { - trees around the sloped sides } \\
\text { and rear side of UPD Main } \\
\text { Library (serve as canopy or } \\
\text { shade) } \\
\text { - vehicular road surrounding the } \\
\text { north, east, and south sides } \\
\text { - several concrete benches along } \\
\text { the top end of the sloped area }\end{array}$ & $\begin{array}{l}\text { - track oval has lower level than } \\
\text { the vehicular road at the east } \\
\text { side (with the sloped area in } \\
\text { between) } \\
\text { - mostly covered with grass or } \\
\text { soil, with few shrubs at certain } \\
\text { spots } \\
\text { - trees at the bottom end of the } \\
\text { sloped area (serve as canopy or } \\
\text { shade) } \\
\text { - several tree logs at the sloped } \\
\text { area converted to seats }\end{array}$ \\
\hline
\end{tabular}




\begin{tabular}{|c|c|c|}
\hline & $\begin{array}{l}\text { - covered grandstand at the east } \\
\text { side (serve as stage area) } \\
\text { - creek running along the north } \\
\text { side (level of depressed } \\
\text { field/area) }\end{array}$ & \\
\hline Original or Intended Function & $\begin{array}{l}\text { - serve as main outdoor area for } \\
\text { sports, events, concerts, large } \\
\text { gatherings, etc. }\end{array}$ & $\begin{array}{l}\text { - serve as landscaped area that } \\
\text { acts as buffer between the track } \\
\text { oval and the vehicular road }\end{array}$ \\
\hline
\end{tabular}

Table 3- Comparison of Study Areas - Student Hangout Areas [HA].

\begin{tabular}{|c|c|c|}
\hline $\begin{array}{c}\text { DESCRIPTION / } \\
\text { CHARACTERISTICS }\end{array}$ & \begin{tabular}{|c|} 
HA1 \\
Vinzons Hill \\
Tambayan Complex \\
\end{tabular} & \begin{tabular}{|c|} 
HA2 \\
Faculty Center \\
Tambayan Area
\end{tabular} \\
\hline Approximate Floor or Land Area & $-2,800$ square meters & $-5,800$ square meters \\
\hline Orientation & $\begin{array}{l}\text { - located at southwest side of } \\
\text { Vinzons Hall (elevated from the } \\
\text { adjacent vehicular road at its } \\
\text { west side of the open space) }\end{array}$ & $\begin{array}{l}\text { - located at south side of Faculty } \\
\text { Center (between the building } \\
\text { and elevated parking lot) }\end{array}$ \\
\hline $\begin{array}{l}\text { Features and Materials } \\
\text { - Ground Cover } \\
\text { - Vegetation } \\
\text { - Surrounding Built Structures and } \\
\text { Landscapes }\end{array}$ & $\begin{array}{l}\text { - concreted open space with few } \\
\text { grass \& soil ground covers } \\
\text { - hangout areas with concrete } \\
\text { benches and tables, metal } \\
\text { supports and G.I. roofing sheets } \\
\text { (surrounding the concreted open } \\
\text { space at the center) } \\
\text { - tall trees nearby (serve as } \\
\text { additional shade) } \\
\text { - food stalls nearby }\end{array}$ & $\begin{array}{l}\text { - sloping open space with grass \& } \\
\text { soil ground covers (paved } \\
\text { walkways passing through the } \\
\text { open space) } \\
\text { - covered hangout areas with } \\
\text { wooden sheds (bamboo) and } \\
\text { thatch roofing (scattered across } \\
\text { the open space) } \\
\text { - tall trees within the area } \\
\text { (hangout areas beneath the tree } \\
\text { canopies) } \\
\text { - food stalls nearby }\end{array}$ \\
\hline Original or Intended Function & $\begin{array}{l}\text { - serve as hangout area for } \\
\text { university-based organizations }\end{array}$ & $\begin{array}{l}\text { - serve as hangout area for } \\
\text { university-based organizations }\end{array}$ \\
\hline
\end{tabular}

\section{STUDIES ON OUTDOOR THERMAL COMFORT AROUND THE WORLD}

The following studies are focused on thermal comfort in outdoor environments, with a handful conducted in hot and humid climates, while some emphasized the importance of studying outdoor thermal comfort for urban design considerations.

A 2014 paper by Lilly Rose Amirtham, Ebin Horrison, and Surya Rajkumar showcases their study regarding the microclimate conditions and thermal comfort in Sathyabama University, an institutional campus at the suburbs of the hot and humid City of Chennai. They investigated how the built geometry (building materials, green cover, etc.) and morphology of the campus affect its microclimate and eventually the outdoor thermal comfort. Aside from field measurements, a survey on thermal sensation was also conducted to analyze the perception of students regarding outdoor thermal environments. The group attempted to identify possible alternatives to improve the thermal comfort of pedestrians using the outdoors during daytime (Amirtham, Horrison, and Rejkumar, 2014). The similarities in the setting (location and temperature) and methodology of their paper with this study strengthen the significance of looking at the outdoor thermal comfort within areas in hot and humid climates to provide favorable microclimatic conditions for outdoors of learning environments such as UP campuses. A research by Kuo-Tsang Huang, Tzu-Ping Lin, and Hsiao-Chi Lien (2015) from Taiwan investigates the thermal comfort and behavioral pattern of users within an outdoor area, particularly in a shaded stepped plaza in the hot and humid City of Taichung. Visual observations, photo and video documentations were used by the researchers to document and analyze the number of outdoor space users in relation to changes in temperature, factors for 
user's selection of location, movement, and length of stay for various activities, and the relationship between the characteristics of thermal environment vis-à-vis behavioral patterns of users. They were able to determine the behavioral patterns of users based on the season and characteristics of the outdoor open space.

Researchers Nastaran Makaremi, Zaky Jaffar, Elias Salleh, and Andreas Matzarakis (2012) explained the thermal conditions of outdoor spaces in Malaysia to identify influential environmental parameters affecting thermal comfort. Their paper demonstrated that plants and vegetation surfaces, shade structures, characteristics of areas, and design of built environment are substantially influential in creating thermally comfortable outdoor environments. In tropical regions, the conditions of thermal comfort in outdoor environments extremely affect people's satisfaction in their usage of open areas. Hence, creating acceptable thermally comfortable outdoor areas is a significant strategy to enhance the quality of urban life and to achieve a sustainable city in the tropics.

A study by Anisha Noori Kakon from Bangladesh and Nobuo Mishima from Japan (2012) looked at the effects of simple and fundamental building forms on microclimate and outdoor thermal comfort in a high dense tropical city of Dhaka in Bangladesh. According to the study, the urban microclimate has direct implications to thermal comfort both indoors and outdoors. In the tropics, the outdoor thermal comfort conditions during daytime are often far above acceptable comfort standards due to intense solar radiation and high solar elevations. The study concluded that the model using less ground coverage and higher buildings offers a better thermal climate in a high-density tropical city.

A more recent study by Inavonna Inavonna, Gagoek Hardiman, and Agus Budi Purnomo (2018) mapped out a framework of assessing the outdoor thermal comfort based on human behavior. Included in the framework are different levels of assessment: physical (form and fabric, microclimate), physiological (thermoregulation, energy balance), psychological (through survey or interview), and social or behavior (observation and/or interview regarding the function of space). For this paper, the focus of discussion include the psychological and social aspects of outdoor thermal comfort, that is, looking into the perception and actual utilization of outdoor open spaces in UP Diliman campus.

\section{METHODOLOGY}

An on-site survey was conducted, with UP Diliman students as respondents, to determine the perception on outdoor open spaces. A survey questionnaire was created and the number of respondents was determined upon discussions with a Social Science consultant. Questions revolve around their usual activities at outdoor open spaces within their preferred time of stay, the factors they consider in selecting the outdoor areas, and other features or elements that students want to be included should the University design or redesign campus outdoor open spaces. Gender, age, and current residence were also asked to know if such information affects the perception on outdoor open spaces.

The survey component of this research aims to identify the considerations of UP Diliman students in selecting outdoor open spaces for various activities. Based on an estimated number of students who frequent the place during regular semester, the sampling intervals were determined for each site. A systematic random sampling of 424 students, with at least 65 respondents per site, spotted at the selected sites in the campus was implemented for the survey in 2014 during the second semester of the academic year (in good weather conditions) through four different time periods. The survey was conducted throughout the day with considerations on different time periods: morning (before $11 \mathrm{am}$ ), noon time (11am to $2 \mathrm{pm})$, afternoon (2pm to $5 \mathrm{pm})$, and late afternoon to evening (after $5 \mathrm{pm}$ ).

Aside from the survey, actual uses of the students on the selected outdoor spaces were also verified through observations during the data gathering period. While the survey was conducted to examine the psychological aspect (perception) regarding the users of the outdoor open spaces, the observations (together with the survey responses) served as basis for analyzing the social aspect (behavior) of the utilization of such spaces. 


\section{DATA RESULTS AND ANALYSIS}

Of the 424 students who responded to the survey, 252 were female, 162 were male, while 10 respondents did not indicate their gender. Majority of the respondents were female students across the six sites, except in VHTC where $52.2 \%$ are males. $80.6 \%$ were living outside the campus out of the 397 respondents who indicated their place of residence. A large number of students residing within the campus used the hangout areas for places to stay, probably due to their friends and companions in their respective organizations.

Table 4 - Distribution of survey respondents by gender.

(Note: tabulation only shows the tally of respondents who answered the question on gender)

\begin{tabular}{|c|c|c|c|c|}
\hline & \multirow{2}{*}{ LOCATION } & \multicolumn{2}{|c|}{ GENDER } & \multirow{2}{*}{$\begin{array}{c}\text { TOTAL } \\
\text { RESPONDENTS } \\
\text { (PER SITE) }\end{array}$} \\
\hline & & Male & Female & \\
\hline BE1 & AS Building Steps & 23 & 42 & 65 \\
\hline BE2 & Main Library Building Steps & 25 & 42 & 67 \\
\hline OF1 & Sunken Garden & 23 & 39 & 62 \\
\hline $\mathrm{OF} 2$ & Track Oval & 30 & 33 & 63 \\
\hline HA1 & Vinzons Hill Tambayan Complex & 36 & 33 & 69 \\
\hline HA2 & Faculty Center Tambayan & 25 & 63 & 88 \\
\hline & TOTAL RESPONDENTS & 162 & 252 & 414 \\
\hline
\end{tabular}

Table 5 - Distribution of survey respondents by residence.

(Note: tabulation only shows the tally of respondents who answered the question on residence)

\begin{tabular}{|c|c|c|c|c|}
\hline & \multirow{2}{*}{ LOCATION } & \multicolumn{2}{|c|}{ RESIDENCE } & \multirow{2}{*}{$\begin{array}{c}\text { TOTAL } \\
\text { RESPONDENTS } \\
\text { (PER SITE) }\end{array}$} \\
\hline & & Within Campus & Off-Campus & \\
\hline BE1 & AS Building Steps & 9 & 54 & 63 \\
\hline BE2 & Main Library Building Steps & 9 & 59 & 68 \\
\hline OF1 & Sunken Garden & 13 & 48 & 61 \\
\hline $\mathrm{OF} 2$ & Track Oval & 7 & 52 & 59 \\
\hline HA1 & Vinzons Hill Tambayan Complex & 24 & 35 & 59 \\
\hline HA2 & Faculty Center Tambayan & 15 & 72 & 87 \\
\hline & TOTAL RESPONDENTS & 77 & 320 & 397 \\
\hline
\end{tabular}

\subsection{Actual Use of Outdoor Open Spaces}

Considering all of the responses across all sites, most of the students used outdoor open spaces within the campus for hanging out and meeting with friends. The abundance of open grounds within the UP Diliman campus makes such spaces an ideal place for said activities, in addition to them being in an open campus where outsiders have access to. The UP Diliman campus is a community in itself, with residences and establishments aside from academic buildings. Some of the respondents also utilized the outdoor open spaces for recreational and leisure activities such as playing outdoor games or enjoying sports, as well as studying.

With regards to the responses per site, students stayed at the AS Steps [BE1] to meet with friends and hang out, which is convenient given its proximity to classrooms, food stalls/kiosks, parking lot, and the Main Library. For the FC Tambayan [HA2], most respondents also used it to hang out and meet with friends, while others utilized said space for recreational and leisure activities such as playing board games, singing, and playing musical instruments. 
Table 6 -Usual activities done by the respondents within the selected outdoor open spaces.

\begin{tabular}{l|c}
\hline $\begin{array}{c}\text { USUAL ACTIVITIES DONE WITHIN } \\
\text { OUTDOOR OPEN SPACES }\end{array}$ & PERCENTAGE (\%) \\
\hline Staying or hanging out & 77.0 \\
\hline Meeting with friends & 73.4 \\
\hline Recreational or leisure activities & 36.8 \\
\hline Studying & 30.4 \\
\hline
\end{tabular}

For Main Library Steps [BE2], respondents said they utilized the space for meeting with friends, hanging out, and studying. The same trend was also evident for Sunken Garden [OF1] with $70.3 \%$ saying they used the space for meeting with friends and $68.8 \%$ for hanging out. $75 \%$ of the respondents in UP Track Oval [OF2] also used the area for hanging out. Aside from passing time and watching varsity players practice, the students also preferred this area for hanging out due to its secluded location away from other public spaces in the campus.
Respondents for VHTC [HA1] likewise utilized said area for hanging out and meeting with friends. The AS Steps, UP Track Oval and VHTC are usually visited and utilized by the students in the afternoon until evening to relax and be with their friends after class hours while the outdoor open spaces with food establishments nearby (VHTC, FC Tambayan and Main Library Steps) were usually visited during noontime and in the afternoon. The accessible Sunken Garden was constantly visited by students any time of day.

Table 7- Time of Stay of Respondents in Selected Outdoor Open Spaces.

\begin{tabular}{c|c|c|c|c|c|c}
\hline $\begin{array}{c}\text { TIME OF DAY WHEN } \\
\text { RESPONDENTS } \\
\begin{array}{c}\text { USUALLY STAY WITHIN } \\
\text { THE PARTICULAR } \\
\text { OPEN SPACE }\end{array}\end{array}$ & $\begin{array}{c}\text { BS Building } \\
\text { Steps }\end{array}$ & $\begin{array}{c}\text { Main Library } \\
\text { Steps }\end{array}$ & $\begin{array}{c}\text { Sunken } \\
\text { Garden }\end{array}$ & Track Oval & VHTC & $\begin{array}{c}\text { FC } \\
\text { Tambayan }\end{array}$ \\
\cline { 2 - 7 } Morning (before 11am) & 6 & 19 & 23 & 9 & 9 & 33 \\
\hline Noon (11am to 2pm) & 11 & 40 & 24 & 17 & 31 & 52 \\
\hline Afternoon (2pm to 5pm) & 36 & 25 & 22 & 42 & 57 & 61 \\
\hline $\begin{array}{l}\text { Late Afternoon to Evening } \\
\text { (after 5pm) }\end{array}$ & 20 & 10 & 30 & 24 & 46 & 31 \\
\hline
\end{tabular}

\subsection{Factors Considered in Selecting Outdoor Open Spaces}

The respondents were asked to rate several factors to consider in selecting outdoor open spaces within the campus regardless of the site where they were surveyed. The scale of consideration ranged from least important (1) to most important (5). Based on the answers, the most important factors identified were natural ventilation, shade from direct sunlight, benches for seating, and outdoor lighting. Environmental parameters (measured through natural ventilation and existence of shade from direct sunlight) appear to be of primary importance for the users of the spaces. This shows that outdoor thermal comfort is an important factor in selecting and utilizing outdoor open spaces for the students. Benches and outdoor lighting were also considered for additional comfort while staying or hanging out at the outdoor open spaces.

Outdoor open spaces with bare ground soil, small areas with adjacent buildings/structures, and concreted or paved flooring are of least importance for the students with regards to their selection and use of such spaces. The students also appear to select outdoor open spaces that are covered with grass or softer ground cover more than bare ground soil or paved flooring. One probable explanation is that concrete flooring reflects heat more than green or landscaped areas that provide a cooler and more relaxing atmosphere.

When asked about the importance of establishments near the outdoor open area, the difference between the responses of male and female students is statistically significant. Although both genders rated this factor as 
important, females put a higher value on the presence of nearby establishments. The accessibility to basic needs such as food, drinks, and other commodities seems to be more important for female students.

Table 8- Importance Ratings (from highest to lowest in average) by Gender.

\begin{tabular}{|c|c|c|c|}
\hline \multirow{2}{*}{$\begin{array}{l}\text { CONSIDERATIONS IN THE SELECTION OF } \\
\text { OUTDOOR CAMPUS SPACES }\end{array}$} & \multicolumn{2}{|c|}{ GENDER } & \multirow{2}{*}{ AVERAGE } \\
\hline & Male & Female & \\
\hline Natural ventilation (wind flow) & 4.51 & 4.60 & 4.57 \\
\hline Shaded or covered from direct sunlight & 4.41 & 4.55 & 4.50 \\
\hline Benches for seating & 4.18 & 4.29 & 4.25 \\
\hline Outdoor lighting & 4.03 & 4.07 & 4.05 \\
\hline Tall trees & 3.86 & 3.81 & 3.83 \\
\hline Presence of establishments nearby & 3.47 & 3.70 & 3.61 \\
\hline Large open field & 3.54 & 3.50 & 3.52 \\
\hline Plants or shrubs within the vicinity & 3.37 & 3.38 & 3.37 \\
\hline Buildings and/or other structures nearby & 3.31 & 3.36 & 3.34 \\
\hline Along or near roads & 3.28 & 3.38 & 3.34 \\
\hline Covered with grass & 3.09 & 3.29 & 3.21 \\
\hline Water features & 3.01 & 3.19 & 3.12 \\
\hline Concreted or paved flooring & 2.96 & 2.96 & 2.96 \\
\hline Small spaces with adjacent buildings/structures & 2.93 & 2.96 & 2.95 \\
\hline Bare ground soil & 2.51 & 2.40 & 2.44 \\
\hline
\end{tabular}

The respondents were also asked to rate the same set of factors according to importance in selecting the particular outdoor open space where they were interviewed. The same results were also derived from the survey. For the UP Track Oval, respondents identified the presence of tall trees and large open fields as important factors in their decision to stay in the area. The presence of tall trees in the outskirts of the Track Oval falls under the shaded area factor since they provide cover from direct sunlight. Aside from this, the large open field serves the purpose of the UP Track Oval as a sports and training facility for the student-athletes.
Observations on site were also made during the time when the survey was conducted to further verify the results. For one, many students stay within the vicinity of Main Library Steps at noontime, most of them having lunch, packed or bought from nearby stores. The same scenario was also observed at FC Tambayan and VHTC, both of which have food establishments close by. Of the six selected sites, these two have large shaded areas during noontime, efficient natural ventilation, and benches or open grounds for seating. Note that the presence of concrete flooring at the center of VHTC makes the area feel hotter during noontime as compared to FC Tambayan. 
Figure 12 - Several food establishments are present within the vicinity of FC Tambayan area.

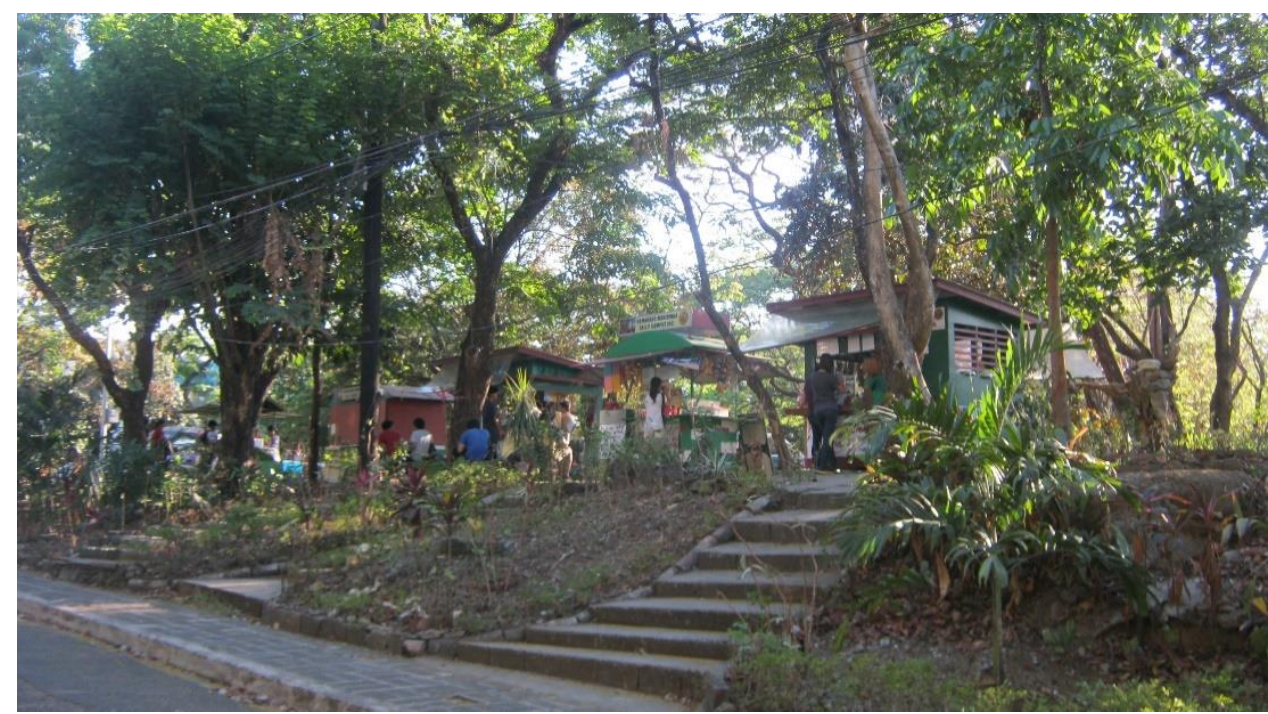

Aside from thermal comfort, the importance of safety and security in selecting outdoor open spaces was also emphasized. Majority of the students considered outdoor lighting as an important factor as fewer people stay at night in outdoor open spaces that have less visual surveillance and outdoor lighting. The flexibility in the use of the outdoor open spaces can be considered a significant factor as well. The AS Steps has many functions such as serving as the main entrance of Palma Hall, a place to stay, hang out, and wait, and a venue for activities like the Oblation Run, Lantern Parade, and protests of some students and militants. Also, although some students were satisfied with the current conditions of the outdoor open spaces, others recommended for improvements of the facilities, as well as repair and regular maintenance of the outdoor open spaces, especially for areas with built structures, especially the provisions of the top six major factors: natural ventilation, shaded or areas covered from direct sunlight, benches for seating, outdoor lighting, tall trees, and close proximity to establishments.

Figure 13- Elementary school faculty, students, and guests gathered at Sunken Garden for field demonstration.

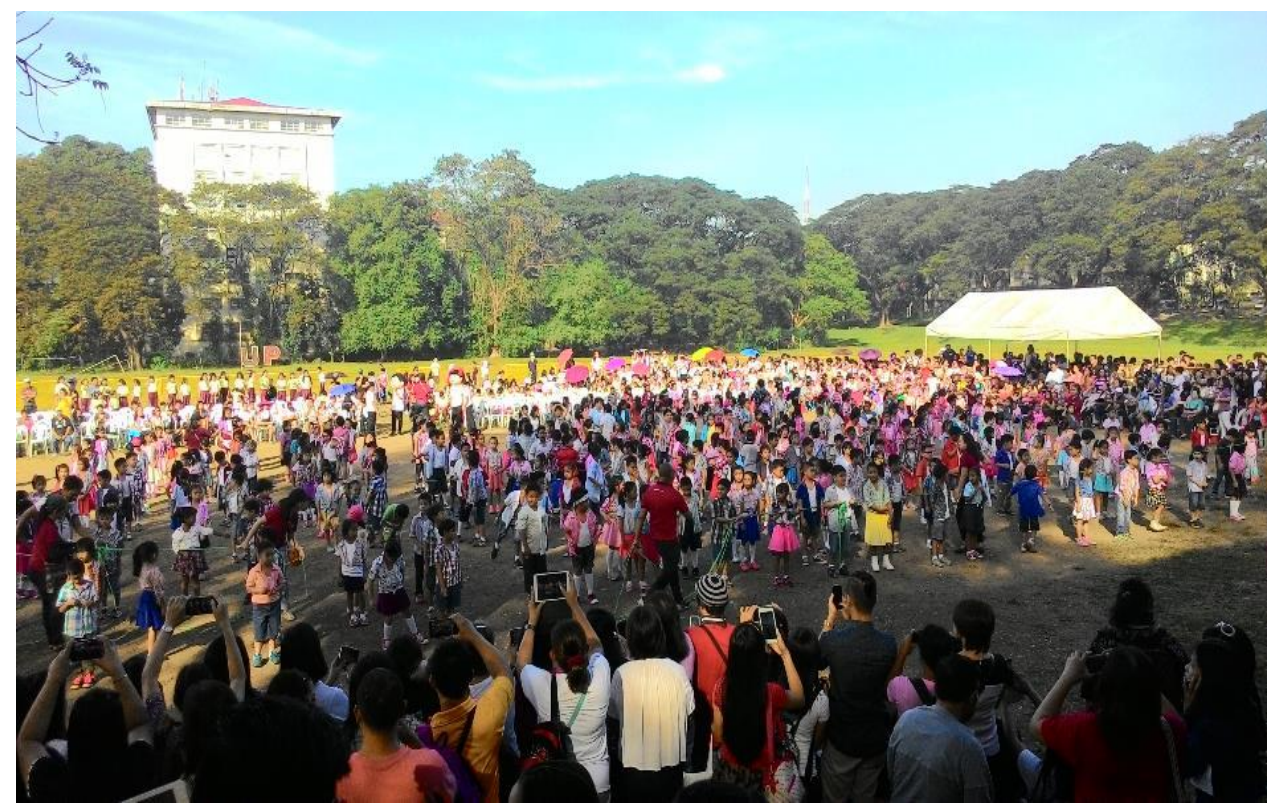




\subsection{Underlying Dimensions in Selection of Outdoor Open Spaces}

Using Factor Analysis, an interdependence technique where all variables are simultaneously considered (Sharma, 1995), four underlying dimensions were identified based on the factors that the respondents considered in selecting outdoor open spaces within campus:

\subsubsection{Nature or Green Factor}

This factor groups variables that describe a space in its natural state - large open field with bare ground soil covered with trees, grass and some plants. In terms of comfort, this type of open space is considered more by males than females (probably due to various activities such as sports that can be done in these areas), and preferred also by those living within the campus. This factor is also considered more by respondents interviewed in the Track Oval and the Sunken Garden, both of which have large green areas, and not much by those interviewed in the VHTC.

Table 9 -Loadings of responses to variables under the Nature or Green Factor.

\begin{tabular}{l|c}
\hline \multicolumn{1}{c|}{ VARIABLES } & LOADINGS \\
\hline Covered with grass & 0.785 \\
\hline Plants or shrubs within the vicinity & 0.727 \\
\hline Tall trees & 0.699 \\
\hline Bare ground soil & 0.637 \\
\hline Large open field & 0.625 \\
\hline
\end{tabular}

\subsubsection{Accessibility Factor}

This factor groups variables that describe a space that has an accessible location and nearby establishments. The level of comfort is probably seen by respondents as synonymous to having access to some basic things like food establishments or comfort rooms. This type of open space is considered more by females than males, and by those living off-campus. This factor is also considered more by respondents interviewed in the AS Steps, and not much by those in Sunken Garden and VHTC. Accessibility factor is somehow related to safety and security of the users, most especially for females.
Table 10 - Loadings of responses to variables under the Accessibility Factor.

\begin{tabular}{l|c}
\hline \multicolumn{1}{c|}{ VARIABLES } & LOADINGS \\
\hline Along or near roads & 0.845 \\
\hline $\begin{array}{l}\text { Buildings and/or other structures } \\
\text { nearby }\end{array}$ & 0.820 \\
\hline Presence of establishments nearby & 0.631 \\
\hline $\begin{array}{l}\text { Small spaces with adjacent } \\
\text { buildings/structures }\end{array}$ & 0.534 \\
\hline
\end{tabular}

\subsubsection{Hardscapes Factor}

This factor groups variables that describe a space which has already undergone some construction and improvements like concrete flooring, installed benches, and water features. This type of open space is considered more by females than males, and by those living off-campus. This factor is also considered more by respondents interviewed in the Track Oval, and not much by those in VHTC. The presence of a water feature not only adds to the aesthetics of the space but also allows cooler air pass through the area.

Table 11 -Loadings of responses to variables under the Hardscapes Factor.

\begin{tabular}{l|c}
\hline \multicolumn{1}{c|}{ VARIABLES } & LOADINGS \\
\hline Water features & 0.700 \\
\hline Concreted or paved flooring & 0.617 \\
\hline Benches for seating & 0.498 \\
\hline
\end{tabular}

\subsubsection{Thermal Comfort Factor}

This factor groups variables that describe a space with natural airflow, lighting, and cover from sunlight - a kind of space for relaxation. This type of open space is considered more by females than males, and by those living offcampus who are looking for such relaxing spaces. This factor is also considered more by respondents interviewed in the FC Tambayan, and not much by those in AS Steps and Track Oval wherein provisions for shade are limited. 
Table 12. Loadings of responses to variables under the Thermal Comfort Factor.

\begin{tabular}{l|c}
\hline \multicolumn{1}{c|}{ VARIABLES } & LOADINGS \\
\hline Natural ventilation & 0.721 \\
\hline $\begin{array}{l}\text { Shaded or covered from direct } \\
\text { sunlight }\end{array}$ & 0.714 \\
\hline Outdoor lighting & 0.461 \\
\hline
\end{tabular}

\section{CONCLUSION}

A number of factors, elements, and features that must be considered in designing and planning for physical development of campus outdoor open spaces have been identified by analyzing the psychological and social aspects of selection and utilization of students of such spaces. These are categorized into: (1) user demographics, (2) actual use of the spaces, including time of use, within the day, (3) perception on outdoor thermal comfort, and (4) preferences. Majority of the respondents were female students and offcampus residents, and although the demographics of the users of the selected outdoor open spaces may be specific only during the period when the survey was conducted, it is crucial to consider the needs of female students when using such spaces, as well as those living away from the campus and preferred to stay within the selected open spaces for various reasons and activities. As per survey results, the frequency of use of the open spaces is high during the afternoon and the evening. This result may be used to properly design open spaces based on the position of the sun for daylighting and provisions for shade, as well as possible sources of wind for natural ventilation.

The quantitative part of the survey was able to draw out the usual activities that the respondents do within the premises of the selected outdoor open spaces. These include staying or hanging out, meeting with friends, recreational or leisure activities, and studying. The outdoor open spaces serve as a gathering area for fun and recreation with friends and schoolmates. These spaces within the campus premises also serve as secondary or alternative venues of learning for students and therefore require adequate elements, features, and facilities to create conducive outdoor areas for studying as well as for other active and passive activities of students as determined in the survey.

Furthermore, the factors that the respondents considered in their selection of outdoor open spaces were identified based on their perception of comfort. The top two responses - natural ventilation and shade or cover from direct sunlight - can be related to the environmental parameters (temperature, humidity, wind speed, mean radiant temperature) that influence outdoor thermal comfort. Other elements or features such as benches for seating, outdoor lighting, tall trees, and presence of establishments nearby were also perceived by the students as important factors to consider in having comfortable outdoor open spaces for their use. This list of factors is also the same set of qualitative responses answered by the students when asked regarding the factors, elements and/or features that must be considered in the designing and planning for physical development of outdoor open spaces in various UP campuses. These factors can be further categorized into four underlying dimensions: nature or green, accessibility, hardscapes, and thermal comfort.

These insights do not only serve as indicators of what an outdoor open space should be but they also justify the significant criteria in designing, developing, and/or improving such spaces within UP campuses. Impressions of preserving and maintaining outdoor open spaces into its natural form and original terrain or setting was also highly preferred by most respondents. Other considerations that were derived from the interview and observations include the following: safety and security, visual surveillance on the outdoor open spaces, flexibility in use or function of such spaces for various types of activities, and regular maintenance and repair of the facilities.

\section{REFERENCES}

1 Ahmed, K.S. (2003). Comfort in Urban Spaces: Defining the Boundaries of Outdoor Thermal Comfort for the Tropical Urban Environments, Energy and Buildings (35), pp.103-110.

2 Amirtham, L.R., Horrison, E., and Rajkumar, S. (2014 December). Study on the Microclimatic Conditions and Thermal Comfort in an Institutional Campus in Hot Humid Climate, $30^{\text {th }}$ International PLEA Conference, 16-18 December 2014, Ahmedabad, India.

3 Alcazaren, P. (2013, February 6). Green and Marooned: The Built and Natural Legacies of UP Diliman [cited 06 February 2013], University of the Philippines Diliman, Available from Internet: http://web- 
old.up.edu.ph/green-and-marooned-thebuilt-and-natural-legacies-of-up-diliman/.

4 Araneta, M.A. (2009). The University Experience in an Urban University: Preserving the Academic Environment of the University of the Philippines Diliman, ESPASYO: Journal of Philippine Architecture and Allied Arts (1), pp.32-41.

5 Dul-loog, V.L. and Galingan, Z.C. (2005). Urban Heat Island Phenomenon: A Look into the Metro Manila Setting, MUHON: A Journal of Architecture, Landscape Architecture and the Designed Environment (2), pp.66-74.

6 Espina, M.A.A. and Espina, C.S.P. (2013, July 29). Principles of a Sustainable UP Diliman Campus, Proceedings of Paliwanagan sa UP Diliman: OVCRD Colloquium and Fair 2013, 29 July 2013, Quezon City, Philippines.

7 Huang, K.T., Lin, T.P., and Lien, H.C. (2015). Investigating Thermal Comfort and User Behaviors in Outdoor Spaces: A Seasonal and Spatial Perspective, Advances in Meteorology, pp.1-11.

8 Inavonna, I., Hardiman, G., and Purnomo, A.B. (2018). Outdoor Thermal Comfort and Behaviour in Urban Area, IOP Conference Series: Earth and Environmental Science (106), pp.1-7.

9 Johansson, E. and Emmanuel, R. (2006, November). The Influence of Urban Design on Outdoor Thermal Comfort in the Hot, Humid City of Colombo, Sri Lanka, International Journal of Biometeorology (51), pp.119-133.

10 Kakon, A.N. and Mishima, N. (2012). The Effects of Building Form on Microclimate and Outdoor Thermal Comfort in a Tropical City, Journal of Civil Engineering and Architecture 6(11), pp.1492-1503.

11 Makaremi, N., Jaffar, Z., Salleh, E., and Matzarakis, A. (2012, August). Study on Outdoor Thermal Comfort in Hot and Humid Context, Proceedings of International Conference on Urban Climates, 6-10 August 2012, Dublin, Ireland.

12 Office of Design and Planning Initiatives (2014). University of the Philippines Master Development Plan: Development Principles and Design Guidelines, Quezon City: University of the Philippines Office of the Vice President for Development.

13 Sharma, S. (1995). Applied Multivariate Techniques. United States of America: John Wiley \& Sons, Inc. 